\title{
Article
}

\section{The development and piloting of the graduate assessment of preparedness for practice (GAPP) questionnaire}

Ray, Mark S, Milston, Anne Marie, Doherty, Paul William and Crean, Stjohn

Available at https://clok.uclan.ac.uk/16838/

Ray, Mark S, Milston, Anne Marie orcid iconORCID: 0000-0002-7491-5639, Doherty, Paul William orcid iconORCID: 0000-0003-3463-9112 and Crean, Stjohn orcid iconORCID: 0000-0001-9336-8549 (2016) The development and piloting of the graduate assessment of preparedness for practice (GAPP) questionnaire. British Dental Journal, 221 . pp. 341-346. ISSN 0007-0610

It is advisable to refer to the publisher's version if you intend to cite from the work. http://dx.doi.org/10.1038/sj.bdj.2016.685.

For more information about UCLan's research in this area go to http://www.uclan.ac.uk/researchgroups/ and search for <name of research Group>.

For information about Research generally at UCLan please go to http://www.uclan.ac.uk/research/

All outputs in CLoK are protected by Intellectual Property Rights law, including Copyright law. Copyright, IPR and Moral Rights for the works on this site are retained by the individual authors and/or other copyright owners. Terms and conditions for use of this material are defined in the policies page. 


\section{MEASURING PREPAREDNESS FOR PRACTICE AMONG FOUNDATION DENTISTS: THE DEVELOPMENT AND PILOTING OF THE GRADUATE ASSESSMENT OF PREPAREDNESS FOR PRACTICE (GAPP) QUESTIONNAIRE.}

\section{GAPP Questionnaire Design.}

Ray, M.S. ${ }^{1}$, Milston, A.M. ${ }^{2}$, Doherty, P.W. ${ }^{3}$ \& Crean, S*4 $^{*}$

${ }^{1}$ GDP, Ravat and Ray Dental Care

${ }^{2}$ Academic Associate Course Leader, University of Central Lancashire

${ }^{3}$ Senior Lecturer in Education Studies, University of Central Lancashire.

${ }^{* 4}$ Executive Dean of the College of Clinical and Biomedical Sciences and Professor of Medicine in Dentistry, Allen Building, Room AL005, University of Central Lancashire,Preston PR1 2HE

\section{ABSTRACT.}

Introduction.

Most new dental graduates in the UK begin their professional career following a year in Dental Foundation Training (DFT). There has been little investigation of how prepared they feel for independent general dental practice across all four domains of the General Dental Council's curriculum 'Preparing for Practice'. This paper describes the development of the Graduate Assessment of Preparedness for Practice (GAPP) questionnaire to address this.

\section{Methodology.}

The GAPP questionnaire was developed and piloted using a cohort of Educational Supervisors (ESs) and Foundation Dentists (FDs).

The questionnaire comprised 3 parts, the first of which collected respondent demographic data. The second was based on Preparing for Practice and was used to develop 34 'competence areas' and required a tick-box response on a 7-category Likert Scale. The third comprised free text questions in order to further explore the subject's responses.

\section{Results.}

Pilot feedback was positive, the statements felt to be clear and unambiguous, allowing them sufficient scope to state their position. The pilot study informed small cosmetic the changes to the GAPP questionnaire and inclusion of a 'comments' column for respondents to qualify their responses.

The pilot results indicated that both FDs and their ESs felt that at ten months of DFT, the FDs were very well prepared for independent general dental practice. 


\section{Discussion.}

The paper describes the important considerations relating to the reliability and validity of the GAPP questionnaire.

\section{Conclusions.}

GAPP appears to be a suitable questionnaire to measure preparedness of new graduates with a degree of reliability and validity. The instrument is designed to be simple to complete and provides a useful analytical instrument for both self-assessment of competence and for wider use within dental education.

\section{INTRODUCTION.}

The General Dental Council (GDC) became involved in dental training months after its first meeting in July 1956 (1). However, it was not until the 1984 Dentist's Act that responsibility for dental education became the GDC's responsibility (2). After its original curriculum The First Five Years (3) in 1982, several iterations have appeared, the latest being Preparing for Practice which redefines the required pre-registration learning outcomes for all registrants (4).

Vocational Training emerged as a result of a profession-wide concern that a bridge between student and professional life needed to be addressed (5). It began as a voluntary scheme before becoming mandatory in 1993 for all UK-qualified dentists wishing to work in the National Health Service (NHS) (6). Regional schemes usually consist of 12 pairings of Foundation Dentists (FDs), and their Educational Supervisors (ESs). They work together in practice for most of the year, the vast majority of them within NHS General Dental Practice (GDP). A Training Programme Director (TPD) is usually appointed to run each scheme and is responsible for their pastoral and educational supervision.

Vocational Training is now termed Dental Foundation Training (DFT), and has a curriculum based on specified learning outcomes against which competence is assessed. The first was published in 2007 by the Committee of Postgraduate Dental Deans and Directors (COPDEND) (7), and was designed for a 2 year Foundation Programme. Since most new graduates only complete the mandatory first DFT year, COPDEND have recently published a draft 2015 curriculum (8) which 'meets contemporary needs of new dental graduates in the critical period of transition to assured and proficient independent NHS practice' (9).

Some authors have expressed concern that DFT is no longer a 'finishing school' for dentists, but is providing core practice and instruction which would previously have been delivered in dental schools (10). This is not a perception limited to the UK, with a similar lack of preparedness reported in other countries such as Hong Kong (based on the traditional UK undergraduate course), (11) Australia and Canada (12). There is a perception by Educational Supervisors that undergraduate training has been 'diluted' and that new graduates entering 
DFT, were not as capable practically as they once were (1). Forty percent of them considering the undergraduate curriculum to be poor in preparing dentists for independent practice (13).

There has been limited research into the preparedness of new graduates for independent practice. Previous studies have sampled regions of the UK $(10,14)$, or looked mainly at elements of general practice $(6,15,16)$.

In order to develop a holistic picture of new graduates' preparedness for independent GDP, across the whole GDC curriculum, there is a need to develop a contemporary questionnaire. This paper addresses that need, and describes the development of the Graduate Assessment of Preparedness for Practice (GAPP) Questionnaire.

\section{METHODOLOGY.}

An extensive literature review of three key areas was carried out prior to developing the GAPP questionnaire.

The Academic Search Complete database was used to search the following terms:

1. Questionnaire and/or questionnaire development

2. Dental Foundation Training and/or Vocational Training

3. UK Dental Education

4. Preparedness for dental practice

The first task in constructing the GAPP questionnaire was to review and understand the information requirement of the study (17). Since the aim was to establish a new dental graduate's preparedness for GDP, it was deemed appropriate to use the learning outcomes set out in the GDC curriculum 'Preparing for Practice' (4) which defines those competencies expected of an independent dental practitioner post-graduation. Preparedness could also be measured against other variables such as age, gender and the school of qualification.

Initial development of the instrument was completed by the researcher and their supervisory team and was subject to the University Ethics Committee. The supervisory team comprised the author, a DFT training Programme Director, Dean of Postgraduate Dental Education, and Senior Lecturer in the University Education Faculty. It was subsequently subjected to vetting by an independent authority to the supervisory team, who was a Dental School Dean. The draft version was then ready for piloting.

The GAPP questionnaire was generated for both FDs and ESs, which were almost identical and comprised three parts.

Part 1 collected descriptive data, including gender, age, school of qualification and length of course ( 4 or 5 years for FD respondents). The ES questionnaire differed in that it included items on length of experience as an ES, and also if they had completed 'VT'. 
Part 2 was based on the competencies set out in the GDC curriculum. The 154 learning outcomes were rationalised to 34 questions, a process that sought to reduce the number of questions, whilst retaining the domain boundaries.

The use of competency statements to develop a measurement of self-efficacy in this study was based on work described by Bandura (18). In order to contextualise the question a in terms of self-efficacy, maintain focus on the question area and reduce the length of individual questions, a single question stem was designed to precede all questions that read: 'How well prepared do you feel for general dental practice in order to...?'

The ES questionnaire was designed to elicit a rating of their current FD on the same competencies, and the stem was modified to read: 'How well prepared do you feel your FD is for general dental practice in order to...?'

Questions were presented in the order that they appeared in the curriculum, and took the form of a continuation of the stem, for example: 'How well prepared do you feel for general dental practice in order to carry out an orthodontic assessment and discuss treatment options with the patient.' The questions are displayed in table 1.

Table 1: The 34 Part 2 GAPP survey questions, preceded by the stem: How well prepared do you feel for general dental practice in order to...?

\begin{tabular}{|l|l||}
\hline CLINICAL & \\
\hline \hline HISTORY TAKING & $\begin{array}{l}\text { Obtain, interpret and record a comprehensive patient history, } \\
\text { accounting for a patient's expectations and anxieties. }\end{array}$ \\
\hline \hline PATIENT & $\begin{array}{l}\text { Complete a patient examination and be able to identify all } \\
\text { relevant systemic and orofacial conditions and diseases. }\end{array}$ \\
\hline \hline $\begin{array}{l}\text { ORTMINODONTIC } \\
\text { ASSESSMENT }\end{array}$ & $\begin{array}{l}\text { Carry out an orthodontic assessment and discuss treatment } \\
\text { options with the patient. }\end{array}$ \\
\hline \hline ACUTE PATIENT & $\begin{array}{l}\text { Appropriately manage the patient presenting in an unscheduled } \\
\text { appointment, including management of acute orofacial trauma, } \\
\text { infection and pain. }\end{array}$ \\
\hline SANAGEMENT & $\begin{array}{l}\text { Appropriately prescribe and / or undertake relevant special tests } \\
\text { to aid diagnosis, including radiography. }\end{array}$ \\
\hline \hline DIAGNOSIS & $\begin{array}{l}\text { Use all relevant data from the history, examination and special } \\
\text { tests, formulate differential diagnoses, and from there, definitive } \\
\text { diagnoses. }\end{array}$ \\
\hline \hline TREATMENT & $\begin{array}{l}\text { Formulate an appropriate treatment plan with the patient, } \\
\text { taking into account the risks and benefits of treatment options. }\end{array}$ \\
\hline
\end{tabular}




\begin{tabular}{|c|c|}
\hline $\begin{array}{l}\text { PREVENTION } \\
\text { ADVICE }\end{array}$ & $\begin{array}{l}\text { Provide relevant, comprehensive, evidence-based preventive } \\
\text { advice to patients. }\end{array}$ \\
\hline REFERRALS & $\begin{array}{l}\text { Refer patients appropriately for advice, assessment or } \\
\text { treatment. }\end{array}$ \\
\hline SAFEGUARDING & $\begin{array}{l}\text { Be able to identify the signs of abuse or neglect in patients and } \\
\text { raise concerns appropriately. }\end{array}$ \\
\hline $\begin{array}{l}\text { DRUG } \\
\text { PRESCRIPTION }\end{array}$ & $\begin{array}{l}\text { Appropriately prescribe and administer drugs and therapeutic } \\
\text { agents. }\end{array}$ \\
\hline PERIODONTAL & $\begin{array}{l}\text { Appropriately assess and manage the health of periodontal and } \\
\text { soft tissues, including monitoring, and prevention treatment. }\end{array}$ \\
\hline $\begin{array}{l}\text { LOCAL } \\
\text { ANAESTHESIA }\end{array}$ & Appropriately administer local anaesthesia. \\
\hline $\begin{array}{l}\text { DIRECT } \\
\text { RESTORATIONS }\end{array}$ & $\begin{array}{l}\text { Appropriately assess and manage caries and non-carious tooth } \\
\text { surface loss, using minimally invasive techniques that are long } \\
\text { lasting, aesthetic and restore or maintain function. }\end{array}$ \\
\hline ENDODONTICS & Appropriately manage uncomplicated endodontic treatment. \\
\hline EXTRACTION & $\begin{array}{l}\text { Appropriately manage uncomplicated extraction of erupted } \\
\text { teeth and roots. }\end{array}$ \\
\hline $\begin{array}{l}\text { SURGICAL } \\
\text { EXTRACTION }\end{array}$ & $\begin{array}{l}\text { Appropriately manage simple surgical removal of teeth and } \\
\text { roots. }\end{array}$ \\
\hline DENTURES & $\begin{array}{l}\text { Assess the need for, design, prescribe and provide } \\
\text { biomechanically sound partial and complete dentures. }\end{array}$ \\
\hline $\begin{array}{l}\text { INDIRECT } \\
\text { RESTORATIONS }\end{array}$ & $\begin{array}{l}\text { Manage indirect restorative procedures that preserve tooth } \\
\text { structure, replace missing or defective tooth structure, maintain } \\
\text { function, are aesthetic and long lasting, and promote soft and } \\
\text { hard tissue health. }\end{array}$ \\
\hline $\begin{array}{l}\text { ORTHODONTIC } \\
\text { APPLIANCE REPAIR }\end{array}$ & Undertake limited orthodontic appliance emergency procedures. \\
\hline $\begin{array}{l}\text { TMJ } \\
\text { MANAGEMENT }\end{array}$ & Recognise and manage temporomandibular joint disorders. \\
\hline $\begin{array}{l}\text { PATIENT AND } \\
\text { PUBLIC SAFETY }\end{array}$ & $\begin{array}{l}\text { Comply with current best practice guidance to ensure delivery of } \\
\text { a high quality service to the patient, including appropriate } \\
\text { documentation of patient records, decontamination procedures } \\
\text { and maintenance of a safe environment. }\end{array}$ \\
\hline $\begin{array}{l}\text { MEDICAL } \\
\text { EMERGENCIES }\end{array}$ & Identify, assess, and manage medical emergencies. \\
\hline $\begin{array}{l}\text { POPULATION } \\
\text { BASED CARE }\end{array}$ & $\begin{array}{l}\text { Understand the current issues relating to inequalities in oral } \\
\text { health, and how to plan to address these needs, including the } \\
\text { role of evidence-based prevention. }\end{array}$ \\
\hline \multicolumn{2}{|l|}{ COMMUNICATION } \\
\hline $\begin{array}{l}\text { PATIENTS AND } \\
\text { PUBLIC }\end{array}$ & $\begin{array}{l}\text { Communicate appropriately, effectively and sensitively at all } \\
\text { times with and about patients, their representatives and the } \\
\text { general public, and obtain informed consent. }\end{array}$ \\
\hline
\end{tabular}




\begin{tabular}{|c|c|}
\hline $\begin{array}{l}\text { OTHER } \\
\text { HEALTHCARE } \\
\text { PROFESSIONALS } \\
\end{array}$ & $\begin{array}{l}\text { Communicate and feedback appropriately with colleagues from } \\
\text { dental and other healthcare professions, and raise concerns } \\
\text { when problems arise. }\end{array}$ \\
\hline $\begin{array}{l}\text { GENERIC } \\
\text { COMMUNICATION } \\
\text { SKILLS }\end{array}$ & $\begin{array}{l}\text { Maintain accurate clinical records and use a range of } \\
\text { communication methods to support clinical practice, within legal } \\
\text { and statutory requirements. }\end{array}$ \\
\hline \multicolumn{2}{|l|}{ PROFESSIONALISM } \\
\hline $\begin{array}{l}\text { PATIENTS AND THE } \\
\text { PUBLIC }\end{array}$ & $\begin{array}{l}\text { Put patients' interests first and act to protect them. Respect } \\
\text { patients dignity and choices, and take into account equality and } \\
\text { diversity. }\end{array}$ \\
\hline $\begin{array}{l}\text { ETHICAL AND } \\
\text { LEGAL }\end{array}$ & $\begin{array}{l}\text { Recognise and act within the GDC's standards and within other } \\
\text { professionally relevant laws, ethical guidance and systems. }\end{array}$ \\
\hline TEAMWORK & $\begin{array}{l}\text { Understand the roles of, and co-operate effectively with other } \\
\text { members of the healthcare team in the interests of patients. }\end{array}$ \\
\hline $\begin{array}{l}\text { DEVELOPMENT OF } \\
\text { SELF AND OTHERS }\end{array}$ & $\begin{array}{l}\text { Demonstrate a commitment to lifelong learning, and the } \\
\text { importance of reflective learning, feedback and development } \\
\text { planning for you and your colleagues. }\end{array}$ \\
\hline \multicolumn{2}{|l|}{$\begin{array}{l}\text { MANAGEMENT } \\
\text { AND LEADERSHIP }\end{array}$} \\
\hline RELATING TO SELF & $\begin{array}{l}\text { Recognise the importance of and demonstrate personal } \\
\text { accountability to patients, the regulator, the team and wider } \\
\text { community. Put patient's interests first and act as their advocate } \\
\text { where appropriate. }\end{array}$ \\
\hline $\begin{array}{l}\text { RELATING TO } \\
\text { OTHERS }\end{array}$ & $\begin{array}{l}\text { Lead, manage and take professional responsibility for the actions } \\
\text { of colleagues and other members of the team involved in patient } \\
\text { care. }\end{array}$ \\
\hline $\begin{array}{l}\text { RELATING TO THE } \\
\text { WORKING } \\
\text { ENVIRONMENT }\end{array}$ & $\begin{array}{l}\text { Recognise and comply with local and national systems and } \\
\text { processes to support safe patient care, including the safe use of } \\
\text { equipment and materials. }\end{array}$ \\
\hline
\end{tabular}

A 7-category rating scale was adopted ranging from completely unprepared, through very poorly prepared, poorly prepared, not well or poorly prepared, well prepared, very well prepared, and finally to completely prepared.

Likert-type scales were originally described with 5 responses (19) significantly expanding the potential information over 'yes/no' or other dichotomous responses (20).

Based on the literature review, it was considered important to balance validity, reliability and discriminating power. Seven categories increased the discriminating power (18), but is postulated to maintain low respondent stress, which accompanies a larger scale (21). An increased number of categories may have severely compromised the ability to appropriately 
name them. The category wording was designed to fit the assumption that the psychometric distance between them from neutrality was equivalent (22).

Although odd-numbered scales may lead to 'drifting towards the mean' and mask positive or negative responses (6), the absence of a central category lead to respondent irritation and increase non-response bias (23).

Part 3 was designed to allow respondents to expand on their previous responses and to elucidate areas of their undergraduate courses which they felt were particularly helpful or unhelpful in terms of their preparedness, and to ascertain their expectations of DFT.

Piloting the Questionnaire.

University ethical approval for the pilot was granted by the host university (STEM 026). Since the proposed population for the pilot was a local DFT Scheme, permission of the local Director of Postgraduate Dental Education was gained with approval of the local IRAS contact.

Participant information and consent sheets were designed to introduce and explain the nature and relevance of the research and encourage participation. In addition to the pilot questionnaire and information sheets, a structured feedback sheet was issued to all participants' views on the GAPP questionnaire's content and format.

The documents were sent as attachments to an email to 14 FDs and 14 ESs (a complete DFT scheme); with clear instructions of how to return the feedback form by email to the author. Documents were sent in MS Word format to facilitate ease of completion.

The pilot study took place in June and since this was during the last quarter of their DFT year, we anticipated may influence their ratings of preparedness.

\section{Data Analysis.}

The quantitative categorical data from Part 2 of the questionnaire was coded to allow statistical analysis. Coding of 1 represented an answer of 'completely unprepared' through to 7 representing 'completely prepared'.

Data was processed using IBM SPSS (Version 20), non-numerical Part 1 questions which were to become variables for statistical analysis required numerical coding, e.g. gender was converted to 1 (female) and 2 (male).

Median scores with IQR were recorded for each question for FDs and ESs. Mean Rank Scores were also generated in order to compare ES and FD responses, which was done using the Mann Whitney $U$ test for 2 unrelated variables, due to the non-normal nature of the data. 
Mean rank scores were considered to be statistically significant if $p \leq 0.05$.

\section{RESULTS.}

\section{Response Rate.}

The response rate was $86 \%$ for FDs and $71 \%$ for ESs.

\section{Pilot Feedback.}

Respondents reported that the GAPP questionnaire took an average of 17 minutes for FDs and 25 minutes for ESs, the range being 7-45 minutes.

The instructions provided were found to be clear and easy to follow by all respondents, the one comment received being 'very clear instructions' in the free text area provided.

All participants bar 1 felt the number of responses to part 2 of the questionnaire gave them a suitable scope to state their position. This ES commented that it was 'impossible to say if the restorations are long lasting'.

Free text suggestions for improvements to the format of part 2 were overwhelmingly positive. The constructive feedback from ESs included a suggestion that there should have been an additional column for comments after each question; a suggestion that removing the central Likert category would stop people choosing the 'simple' middle option, and a comment that questions were too long and multifaceted.

FDs were also very positive. Constructive feedback also included the suggestion of a comments column, and that if presented in landscape format the font could be larger.

Most respondents (86\%) felt that part 3 of the questionnaire gave them adequate opportunity to express their feelings, although three respondents felt the wording of the penultimate question was ambiguous.

The GAPP questionnaire was altered as a result of the feedback. The page orientation was converted to landscape, which also facilitated the addition of a 'comments' column to part 2 , allowing respondents to clarify the reason for their categorical responses. Wording of the penultimate question in part 3 was also amended.

\section{GAPP Questionnaire Pilot Results.}

$20 \%$ of ESs respondents were female which contrasted with a predominantly female $(75 \%)$ FDs proportion of respondents.

The median (IQR) and mode of all questions for FDs and ESs are displayed in Table 2Fable4,8.

\section{Table 2: GAPP PILOT SURVEY DESCRIPTIVE DATA.}




\begin{tabular}{|c|c|c|}
\hline \multirow[t]{2}{*}{ PART 2 QUESTION AREA } & \multicolumn{2}{|c|}{ MEDIAN (IQR) } \\
\hline & FD & ES \\
\hline \multicolumn{3}{|l|}{ CLINICAL } \\
\hline HISTORY TAKING & $6(6,7)$ & $6(5,6.25)$ \\
\hline PATIENT EXAMINATION & $6(5,6)$ & $5.5(5,6.25)$ \\
\hline ORTHODONTIC ASSESSMENT & $5(4,5)$ & $5(4,5)$ \\
\hline ACUTE PATIENT MANAGEMENT & $6(5,6)$ & $6(5,6)$ \\
\hline SPECIAL TESTS & $6(6,7)$ & $6(5,7)$ \\
\hline DIAGNOSIS & $6(5,6)$ & $6(5,6.25)$ \\
\hline TREATMENT PLANNING & $6(5.25,6)$ & $5(5,6.25)$ \\
\hline PREVENTION ADVICE & $7(6,7)$ & $6(5.75,7)$ \\
\hline REFERRALS & $6(6,7)$ & $6(5,7)$ \\
\hline SAFEGUARDING & $5(5,6)$ & $5.5(4.75,6.25)$ \\
\hline DRUG PRESCRIPTION & $6(5,7)$ & $6(5,7)$ \\
\hline PERIODONTAL & $6(6,7)$ & $6(5,7)$ \\
\hline LOCAL ANAESTHESIA & $7(6,7)$ & $6(6,7)$ \\
\hline DIRECT RESTORATIONS & $6(6,7)$ & $6(5,7)$ \\
\hline ENDODONTICS & $6(5.25,6)$ & $5.5(5,6.25)$ \\
\hline EXTRACTION & $6(5.25,6)$ & $6(5,6.25)$ \\
\hline SURGICAL EXTRACTION & $5(4,5)$ & $5(4.75,5)$ \\
\hline DENTURES & $5.5(5,6)$ & $5(4.75,6.25)$ \\
\hline INDIRECT RESTORATIONS & $6(5,6)$ & $5(4.75,6.25)$ \\
\hline ORTHODONTIC APPLIANCE REPAIR & $4(3,4)$ & $4(2.75,4.25)$ \\
\hline TMJ MANAGEMENT & $5(4,5)$ & $5(4,5)$ \\
\hline PATIENT AND PUBLIC SAFETY & $6(5.25,6.75)$ & $6(5,6.25)$ \\
\hline MEDICAL EMERGENCIES & $6(5,6.75)$ & $5.5(5,6)$ \\
\hline POPULATION BASED CARE & $6(5,6)$ & $5(4.75,5.5)$ \\
\hline \multicolumn{3}{|l|}{ COMMUNICATION } \\
\hline PATIENTS AND PUBLIC & $6(6,7)$ & $5(5,6.25)$ \\
\hline OTHER HEALTHCARE PROFESSIONALS & $6(6,6)$ & $5(5,6.25)$ \\
\hline GENERIC COMMUNICATION SKILLS & $6.5(6,7)$ & $6(5,7)$ \\
\hline \multicolumn{3}{|l|}{ PROFESSIONALISM } \\
\hline PATIENTS AND THE PUBLIC & $7(6,7)$ & $6(5,7)$ \\
\hline
\end{tabular}




\begin{tabular}{|l|c|c|}
\hline ETHICAL AND LEGAL & $6.5(6,7)$ & $6.5(5,7)$ \\
\hline TEAMWORK & $7(6,7)$ & $6(5,7)$ \\
\hline DEVELOPMENT OF SELF AND OTHERS & $7(6,7)$ & $6(5,7)$ \\
\hline MANAGEMENT AND LEADERSHIP & & \\
\hline RELATING TO SELF & $6.5(6,7)$ & $6(5,7)$ \\
\hline RELATING TO OTHERS & $6(5.25,6.75)$ & $5(4.75,5.5)$ \\
\hline RELATING TO THE WORKING ENVIRONMENT & $6(5.25,7)$ & $5(4.75,6.25)$ \\
\hline
\end{tabular}

\begin{tabular}{|c|c|c|c|c|}
\hline & $\mathrm{FD}$ & ES & FD & ES \\
\hline \multicolumn{5}{|l|}{ CLINHCAL } \\
\hline HISTORY TAKING & 6 & 5 & $6(5,6)$ & $5(5,6)$ \\
\hline PATIENT EXAMINATIOA & 5 & 5 & $5(5,6)$ & $5(5,5)$ \\
\hline ORTHODONTIC ASSESSMENT & 5 & 5 & $5(4,5)$ & $4(4,5)$ \\
\hline ACUTE PATIENT MANAGEMENT & 5 & 5 & $5(5,5)$ & $5(4,5)$ \\
\hline SPECIAL TESTS & 5 & 5 & $5(5,6)$ & $5(5,5)$ \\
\hline DIAGNOSIS & 5 & 5 & $5(5,6)$ & $5(4,5)$ \\
\hline TREATMENT PLANNING & 5 & 5 & $5(5,6)$ & $5(4,5)$ \\
\hline PREVENTION ADVICE & 6 & 6 & $6(5,6)$ & $5(5,6)$ \\
\hline REFERRALS & 5 & 5 & $5(5,6)$ & $5(4,5)$ \\
\hline SAFEGUARDING & 5 & 5 & $5(4,5)$ & $4(4,5)$ \\
\hline DRUG PRESCRIPTIOA & 5 & 5 & $5(5,6)$ & $5(4,5)$ \\
\hline PERIODONTAL & 5 & 6 & $6(5,6)$ & $5(5,6)$ \\
\hline LOCALANAESTHESIA & 6 & 6 & $6(6,7)$ & $5(5,6)$ \\
\hline DIRECT RESTORATIONS & 5 & 6 & $6(5,6)$ & $5(4,5)$ \\
\hline ENDODONTICS & 5 & 5 & $5(5,6)$ & $5(4,5)$ \\
\hline EXTRACTION & 5 & 6 & $6(5,6)$ & $5(4,5)$ \\
\hline SURGICAL EXTRACTION & 4 & 4 & $4(3,5)$ & $4(3,5)$ \\
\hline DENTURES & 5 & 5 & $5(4,5)$ & $4(4,5)$ \\
\hline INDIRECT RESTORATIONS & 5 & 5 & $5(4,5)$ & $4(4,5)$ \\
\hline ORTHODONTIC APPLIANCE REPAIR & 4 & 4 & $4(3,4)$ & $3(3,4)$ \\
\hline TMJ MANAGEMENT & 5 & 4 & $4(3.25,5)$ & $4(4,5)$ \\
\hline PATIENT ANDPUBLIC SAFETY & 5 & 5 & $5(5,6)$ & $5(4.5,5.5)$ \\
\hline AAEDICALEMERGENCIES & 5 & 5 & $5(5,6)$ & $5(4,5)$ \\
\hline POPULATION BASEDCARE & 5 & 5 & $5(5,6)$ & $5(4,5)$ \\
\hline \multicolumn{5}{|l|}{ COMAUNICATION } \\
\hline PATIENTS AND PUBLIC & 6 & 6 & $6(5,7)$ & $5(5,6)$ \\
\hline $\begin{array}{l}\text { OTHER HEALTHCARE } \\
\text { PROFESSIONALS }\end{array}$ & 5 & 5 & $5(5,6)$ & $5(5,6)$ \\
\hline
\end{tabular}




\begin{tabular}{|c|c|c|c|c|}
\hline GENERIC COMAMUNICATION SKILLS & 6 & 6 & $6(5,6)$ & $5(5,6)$ \\
\hline PATIENTS ANDTHE PUBHC & 6 & 6 & $6(5,7)$ & $5(5,6)$ \\
\hline ETHICAL ANDLEGAL & 6 & 6 & $6(5,7)$ & $5(5,6)$ \\
\hline TEAMWORK & 6 & 6 & $6(5,7)$ & $5(5,6)$ \\
\hline $\begin{array}{l}\text { DEVELOPAENT OF SELF AND } \\
\text { OTHERS }\end{array}$ & 6 & 6 & $6(5,7)$ & $5(5,6)$ \\
\hline RELATING TOSELF & 6 & 6 & $6(5,7)$ & $5(5,6)$ \\
\hline RELATINGTOOTHERS & 5 & 5 & $5(5,6)$ & $5(4,5)$ \\
\hline $\begin{array}{l}\text { RELATING TOTHE WORKING } \\
\text { ENVIRONAEENT }\end{array}$ & 5 & 5 & $5(5,6)$ & $5(4,5)$ \\
\hline
\end{tabular}

Table 4.4 shows thatFDs generally felt 'well prepared' for independent practice in 7 of the 24 Clinical areas with 143 areas felt to be 'very well prepared'. They felt 'completely prepared' in prevention advice and administering local anaesthesia.

In only one area (orthodontic appliance repair) ranked lower ('not well or poorly prepared'). They did not feel 'poorly prepared' in any clinical area.

In all areas of Professionalism they felt 'completely prepared' while in the Communication and Management Domains, they felt 'very well prepared' or 'completely prepared'.

The ESs also rated FDs 'well prepared' in 7 of the Clinical areas, with 16 areas rated as 'very well prepared'. The ESs felt the FDs were not 'completely prepared' in any area. They also felt that FDs were 'not well or poorly prepared' for orthodontic appliance repair.

The ESs also felt the FDs were 'completely prepared' in the ethical and legal area of Professionalism with all of the other non-clinical areas rated as 'very well prepared' or 'well prepared'.

\section{Comparison of ES and FD results.}

From the median (IQR) descriptive statistics in Table 2 we observe that the trend was that ESs tended to score lower than the FDs. This applied for 26 of the 24 questions, while 4 areas were rated the same; orthodontic assessment, acute patient management, drug prescription and TMJ management. Although marginal, the areas of diagnosis, safeguarding and surgical extractions were scored slightly higher by ESs.

When ES and FD responses had mean rank scores analysed statistically using the Mann Whitney $U$ non-parametric test, there was only 1 statistically significant difference identified in the Communication Domain; patients and the public. ESS rated their FDs significantly worse than the FDS rated themselves in this area with $p=0.038$. 


\section{DISCUSSION.}

\section{GAPP Questionnaire Results.}

The results appear to illustrate that FDs feel well prepared for independent general dental practice at 10 months of DFT. This appears to be a view shared by their ESs. Despite a general trend for the ESs to rate FD preparedness slightly lower than the FDs themselves, this was only significant for communication with the patients and public.

Orthodontic appliance repair stood out as being the lowest ranked competency area by both populations. This may be explained by the NHS GDS contractual changes that came into force in 2006 that excluded many general dental practitioner's (GDPs) ability to claim for orthodontic work on the NHS. We believe this has largely stopped the small amount of NHS orthodontics GDPs did prior to the contractual changes.

These results should be viewed with caution due to the pilot sample size.

\section{Questionnaire Validity.}

In simple terms, a questionnaire is valid if it measures what it purports to measure. Cronbach stated: 'One validates, not a test, but an interpretation of data arising from a specified procedure' (24).

It was felt essential that the GAPP questionnaire was designed to facilitate capture of results in the form of;

'FDs reported their preparedness in (specific question area) as (Likert scale response) at this particular time in their postgraduate career; and

'ESs reported that they feel their FD's preparedness in (specific question area) as (Likert scale response) at this particular time in their postgraduate career.

\section{Content Validity.}

In order to be content valid, a questionnaire needs to accurately reflect a specific domain of content. This concept requires careful consideration when constructing a questionnaire such as this.

Nunnally stated that content validity 'rests mainly on appeals to reason regarding the adequacy with which important content has been sampled' (22).

Many qualitative studies use questionnaires to attempt to describe an abstracted criterion (see below) and questions are developed to collectively define that criterion. An excellent example given by Carmines and Zeller (25) being a child's mathematics test including all 
forms of calculation (not just addition) in order to give a judgement of their overall mathematics proficiency.

With this GAPP questionnaire, we attempt only to describe self- reported preparedness by FDs, or preparedness perceived by their ESs, and not an abstract criterion such as competence.

This means that each question item in the GAPP questionnaire, when considered alone should accurately reflect that area of content.

One of the limitations of this GAPP questionnaire is the compound nature of some of the questionnaire's questions, subsequent to the stem, e.g. Question 8:

(Stem) How well prepared do you feel for general dental practice in order to...?

Appropriately manage the patient presenting in an unscheduled appointment, including management of acute orofacial trauma, infection and pain.

It is clear to us all that there are several skills within this area, and conceivably a respondent may struggle to provide a single response. They may feel 'very well prepared' to manage acute infections, but 'poorly prepared' to deal with orofacial trauma.

In couching the sentence within a heading of 'acute patient management' we hoped that the respondent would describe their overall preparedness in this area.

The alternative to this would be to have used each competency statement in Preparing for Practice as a separate question item, making part 2 of the questionnaire 154 questions long, instead of 34. Due to the inherent risks of questionnaire fatigue with so many questions, we opted to maintain high content validity.

In terms of the content validity of the GAPP questionnaire as a whole in measuring selfreported preparedness, we believe that because it is the only questionnaire to have incorporated all of the elements of the new GDC curriculum, a valid perception may be gleaned, as opposed to other questionnaires which utilise limited (often only clinical) competencies.

\section{Criterion-Related (Predictive) Validity.}

One critical question that as yet remains unanswered relates to the ability of this GAPP questionnaire to predict new graduates performance.

Further work is planned, in order to establish the performance of new graduates, and how this performance relates to their self-assessment (or their ES assessment) of preparedness in particular tasks. Then a clear relationship can be formulated between the criterion variable (performance) and their empirical scoring on the GAPP questionnaire. 
There are clear benefits in doing so; surveying dental trainees or graduates at any level will allow a picture of their likely performance 'in vivo' to be drawn, and decisions made as to their readiness to treat patients safely.

\section{Construct Validity.}

At this early stage in the development of this GAPP questionnaire, we have not attempted to develop theorised constructs based on responses to the questionnaire, but we have highlighted the potential benefits this may bring.

\section{Questionnaire Reliability.}

For the reasons outlined above, we believe the results from the GAPP questionnaire will be valid, if reported carefully and not extrapolated. But how reliable is it?

Due to the specific timing of the questionnaire use in this study, and the huge logistical implications of retesting and tracking responses this was not carried out.

Arguably, given the huge learning curve commonplace in DFT, even a small time period between retests may have introduced significant error in the assessment of reliability. How would we be able to determine if a higher score was usually given in a retest because of increased confidence or experience of the FD, or due to an unreliable test?

The issue of reactivity (scores changing due to prior exposure to a previous test) is enhanced significantly the sooner the retest is carried out.

Statistical analysis of Likert-type questionnaires can often help to indicate the degree of reliability. The statistical tests such as Cronbach's alpha (26) or KR20 (27) are invaluable on a questionnaire design, where multiple elements attempt to represent a criterion or construct.

The use of statistical methods to analyse GAPP questionnaire reliability are unfortunately useless. More importantly their use is fundamentally flawed, and could lead to false assertions of its reliability.

Cronbach's Alpha (26) necessitates the comparison of pairs of responses from the questionnaire, resulting in a score of internal consistency ranging from 1 (perfectly reliable) to 0 (completely unreliable). Thus if several questions were concerned with self-esteem or some other abstract construct, answers to the questions should be similar, and alpha would generate a meaningful measure of reliability (to measure self-esteem).

In this GAPP questionnaire, each item reflects a very different series of competencies from the GDC curriculum. We are interested in the feelings of preparedness in these individual areas, rather than attempting to abstract the data to a construct such as 'general competence'. The danger of pairing curricular elements in such a statistical test is clear, and would give an alpha value which would be meaningless. 
We intend to use the GAPP questionnaire to elucidate the feelings of preparedness of FDs within 2 months of DFTs commencement. We also propose to elicit their ESs assessment of their preparedness at the same time point by using the ES version of the GAPP questionnaire. The questionnaires will be distributed and returned by post using the Training Programme Directors of the DFT schemes as the distribution point. Approval has already been granted by COPDEND for this.

Our suggestion would be that this questionnaire should be repeated annually as each new cohort of dentists enters DFT, in order to develop a picture of where they perceive their training to date has prepared them, and act as a stimulus to develop their DFT programmes prospectively.

\section{CONCLUSIONS.}

GAPP is the first questionnaire to be published which can be used to establish self-reported preparedness of FDs and the reported preparedness of FDs by their ESs across all domains of the GDC curriculum.

GAPP appears to be a valid measure of preparedness for practice among graduates and their supervisors. The instrument is simple to complete and provides a useful analytical instrument for both self-assessment of preparedness and for wider use within Dental Education. It is one method by which those responsible for undergraduate and postgraduate training to compare graduates competency based on objective performance under clinical assessment with students' subjective perceptions of competence, highlighting useful areas for support as FD enter DFT settings. It also serves as a before and after measure for both FDs and ESs to assess how perceptions of the FD's preparedness changes during DFT.

The pilot results appear to show that FDs are well prepared for independent practice at ten months of DFT.

The GAPP questionnaire will be used to establish preparedness of new graduates from both ESs and FDs perspectives in a nationwide questionnaire involving all DFT Schemes in England and Wales.

It may be that further work to criterion validate the questionnaire (as a predictive instrument) may allow it to be used as an indicator to help judge where focussed interventions within the continuing professional development of a dentist may be required.

\section{Limitations of the pilot.}

The authors acknowledge the relatively small sample size of the pilot study, but were satisfied that the high response rate gave sufficient feedback on which to develop the final GAPP questionnaire.

\section{ACKNOWLEDGEMENTS.}


The authors would like to express their appreciation to the pilot study participants, and Professor Callum Youngson for his advice during the GAPP questionnaire development.

\section{REFERENCES.}

1 General Dental Council. The First 50 Years. General Dental Council: London; 2006.

2 The Dentists Act, 1984. http://www.legislation.gov.uk/ukpga/1984/24/enacted (Accessed 20 November 2015).

3 General Dental Council. The First Five Years - A Framework for Undergraduate Dental Education , $2^{\text {nd }}$ ed. General Dental Council: London; 2002.

4 General Dental Council. Preparing for Practice. Dental Team Learning Outcomes for Registration. General Dental Council: London; 2012.

5 Levine RS. Experience, skills and knowledge gained by newly qualified dentists during their first year of general practice. Brit Dent J 1992: 17: 97-102.

6 Patel J, Fox K, Grieveson B, Youngson CC. Undergraduate training as preparation for vocational training in England: A questionnaire of vocational dental practitioners' and their trainers' views. Brit Dent J 2006 Sept; suppl: 9-15.

7 Cabot LB, Radford DR. Are graduates as good as they used to be? Brit Dent J 1999: 186: 318-319.

8 COPDEND. Dental Foundation Training Curriculum 2015 [Draft]. http://www.copdend.org//data/files/Foundation/DFTCurriculum FINALDRAFT 2015\%20(2). pdf(Accessed 20 November 2015).

9 COPDEND. Interim Dental Foundation Training Curriculum \& Assessment Framework Guidance 2013-14.

http://www.copdend.org//data/files/Foundation/Interim\%20DFT\%20curriculum\%20201314.pdf(Accessed 20 November 2015).

10 Clow R, Mehra S. Evaluation of vocational training of dentists in three different regions. Brit Dent J 2006: 201: 774-778.

11 Mc.Grath CM, Corbet EF. Do dental graduates of the University of Hong Kong (19972001) perceive themselves prepared for dental practice? HK Dent J 2005: 2: 84-91.

12 Greenwood LF, Townsend GC, Wetherell JD, Mullins GA. Self-perceived competency at graduation: A comparison of dental graduates from the Adelaide PBL curriculum and the Toronto traditional curriculum. Eur J Dent Ed 1999: 3: 153-158. 
13 Bartlett DW, Coward PY, Wilson R, Goodsman D, Darby J. Experiences and perceptions of vocational training reported by the 1999 cohort of vocational dental practitioners and their trainers in England and Wales. Brit Dent J, 2001: 191: 265-270.

14 Kay EJ, Blinkhorn AS. Scottish dental students' views on their undergraduate training. Brit Dent J, 1987: 162: 317-319.

15 Murray FJ, Blinkhorn AS, Bulman JS. An assessment of the views by recent graduates on their undergraduate course. Eur J Dent Educ 1999: 3: 3-9.

16 Silversin JB, Shafer SM, Smales FC, Sheiham A. British dentists and final year British and United States students' opinions about their undergraduate training. Brit Dent J, 1974: 137: 161-168.

17 Ambrose DM, Anstey JR. Questionnaire Development: Demystifying the Process. Int Man Rev, 2010: 6(1): 84-91.

18 Garner WR. Rating scales, discriminability and information transmission. Psychol Rev, 1960: 67: 343-352.

19 Likert R. A technique for the measurement of attitudes. Arch Psychol, 1932; 140: 1-55.

20 Linacre JM. Optimizing Rating Scale Category Effectiveness. J Appl Measurement, 2002: 3(1): 85-106.

21 Nunnally JC. Psychometric Theory. New York: McGraw-Hill; 1967.

22 Cummins RA, Gullone E. Why we should not use 5-point Likert scales: The case for subjective quality of life measurement. Proceedings, second international conference on quality of life in cities. Singapore: National University of Singapore; 2000.

23 Burns N, Grove SK. The practice of nursing research conduct, critique \& utilization. Philadelphia: W.B. Saunders and Co; 1997.

24 Cronbach LJ. Test Validation. In Educational measurement, $2^{\text {nd }}$ ed. Washington DC: American Council on Education; 1971.

25 Carmines EG, Zeller RA. Reliability and validity assessment. Quantitative applications in the social sciences. Beverley Hills: Sage; 1979.

26 Cronbach LJ, Coefficient alpha and the internal structure of tests. Psychometrika, 1951: 16: 297-334. 
27 Kuder GF, Richardson MW. The theory of estimation of test reliability. Psychometrika, 1937: 2: 151-160. 